\title{
Hearing Loss, Tinnitus and Pineal Germinoma: Parinaud Dorsal Midbrain Symdrome Revisited
}

\section{Rithvik Marri ${ }^{1}$, Harini Rao², Diana S Osorio ${ }^{1}$, Jonathan L Finlay ${ }^{1}$ \\ ${ }^{1}$ Division of Pediatric Hematology/Oncology, Nationwide Children's Hospital, The Ohio State University, USA ${ }^{2}$ Children's Hospital of New Jersey, Newark Beth Israel Medical Center, USA}

\section{*Corresponding author:}

\section{Diana S. Osorio}

Division of Pediatric Hematology/Oncology,

Nationwide Children's Hospital

The Ohio State University, Columbus, Ohio, USA

Received : December 11, 2018

Published : January 17, 2019

\section{Abstract}

Background: Hearing impairment and tinnitus are forgotten features of Parinaud Syndrome originally discussed by Henri Parinaud in 1886.

Methods: A retrospective case series of 3 patients who presented with pineal region germinomas and hearing loss.

Results: A 15 years old male presented with morning headaches, blurred vision, bilateral papilledema, failure of upward gaze, bilateral tinnitus and decreased hearing acuity. Post-operatively, his tinnitus disappeared completely and his hearing normalized within one week. A 16 years old male presented with complete left sided hearing impairment with cranial nerve III palsy, right eye ptosis and worsening right-sided hearing loss; he had minimal recovery of his hearing after therapy. A 46 years old with a recurrent germinoma presented with hydrocephalus, bilateral ophthalmoplegia and hearing loss; his hearing loss improved after surgical resection.

Conclusion: These case reports serve as a reminder that hearing loss can also be a component of Parinaud Syndrome.

Keywords: Hearing loss; Pineal region tumor; Germinoma; Germ cell tumor; Tinnitus; Parinaud Syndrome

\section{Introduction}

Henri Parinaud was a French ophthalmologist and neurologist who in 1886 famously described a syndrome in patients with upward gaze paralysis, convergence nystagmus, accommodation paralysis and dilated pupils, some of which he thought were associated with a central lesion. He also described patients with hearing loss in association with this constellation of signs and symptoms, and he was "more disposed to believe that the troubles of hearing and of vision arise from the same central lesion [1]. He concluded by suggesting that "the lesion, instead of directly attacking the bulbo-pontal nuclei, is situated in a neighboring centre, which acts immediately upon them, and it appears that this centre may be the tubercula quadrigemina [1].

Posner and Horrax (1945) noted that central deafness is a frequent symptom of pineal tumors concomitant with limitations of ocular conjugate upward movement [2]. However, Parinaud's Syndrome has since been defined in several publications with the specific inclusion of upward gaze paralysis, ignoring hearing dysfunction [3-5]. Cogan (1964) defined the syndrome as vertical upward gaze paralysis combined with paralysis of convergence and pupillary areflexia [3]. Biemond 
(1979) suggested that the syndrome should be defined as paralysis of upward gaze with pupillary disturbances and sometimes absent convergence [4]. Mumenthaler (1979) defined Parinaud syndrome as paralysis of vertical upward gaze, weakness of convergence, and abolished pupillary reaction to light [5].

The three cases below describe our individual experience with patients who presented with significant hearing impairment concomitant with other symptoms indicative of Parinaud syndrome, as originally defined.

\section{Case Reports}

\section{Patient 1}

A 15 years old Indonesian male presented with morning headaches over several months, associated with emesis, blurred vision, bilateral papilledema, failure of upward gaze, bilateral tinnitus and decreased hearing acuity. His brain and spine magnetic resonance imaging (MRI) revealed a large posterior third ventricular mass without intracranial or spinal leptomeningeal spread, and a ventriculo-peritoneal shunt was placed in Singapore. Both his serum and cerebrospinal fluid (CSF) alpha-fetoprotein (AFP), and beta-human chorionic gonadotropin (HCG $\beta$ ) were reportedly normal, leading to a presumptive diagnosis of pineoblastoma. Upon transfer to Los Angeles for further management, magnetic resonance spectroscopy demonstrated a markedly elevated lipid peak with no elevations in n-acetyl-aspartate (NAA), choline or creatine, typical of pure germinoma. His sensorineural hearing loss was confirmed bilaterally and a gross total resection was performed with histopathological confirmation of pure germinoma by both light microscopy and comprehensive immunohistochemical staining. His repeat lumbar CSF and serum tumor markers were normal. Post-operatively, his tinnitus disappeared completely and his hearing normalized, both within one week. He was enrolled onto a North American Children's Oncology Group (COG) protocol and received 4 cycles of carboplatin and etoposide followed by ventricular field (18Gy) irradiation with primary site boost (30Gy). He is now greater than 4.5 years from initial diagnosis without evidence of residual or recurrent tumor, and with normal hearing.

\section{Patient 2}

A 16 years old Filipino male with left-sided tinnitus for 3 months was treated with phencyclidine (PCP) for an ear infection. As his left-sided tinnitus worsened, otolaryngologic evaluation noted left-sided ptosis, development of right-sided tinnitus and he was started on steroids for presumptive Bell's palsy. A brain MRI showed bilateral cranial nerve (CN) 5, 7, 8 and left-sided CN 3 thickening, pineal gland involvement and leptomeningeal enhancement. He was referred to a tertiary care center for diagnostic workup for $\mathrm{CN}$ abnormalities, and was presumed initially to harbor infectious meningitis. A spine MRI showed lumbar leptomeningeal enhancement. After repeat lumbar punctures, the CSF revealed pleocytosis and positive $\beta$-D-glucan; fungal meningitis was presumed and he was treated with voriconazole and amphotericin. Whole body positron emission tomography (PET), bone marrow aspirates and other infectious disease/immunodeficiency investigations were negative. His symptoms advanced to complete left-sided hearing impairment with choroidal neovascularization, CN3 palsy, right eye ptosis and worsening right-sided hearing loss. Finally, a biopsy of a lumbar spinal leptomeningeal lesion at the $L 4$ level revealed pure germinoma with octamer-binding transcription factor 4 (OCT-4) and placental alkaline phosphatase (PLAP) positivity on immunohistochemical staining. An audiogram confirmed sensorineural hearing loss on the right and no measurable hearing on the left. The patient was treated according to a COG clinical trial with 4 cycles of carboplatin and etoposide followed by cranio-spinal proton beam irradiation with 23.4 Gy craniospinal and $12 \mathrm{~Gy}$ involved field. His facial weakness improved but he remains deaf in his left ear and has $8 \%$ hearing on the right. He is now greater than 4 years from initial diagnosis without evidence of residual or recurrent tumor, and with stable hearing loss.

\section{Patient 3}

A 46 years old male was assessed with acute hydrocephalus, Parinaud syndrome and diabetes insipidus. He had first presented 26 years earlier with computed tomography (CT) and MRI findings of a pineal region mass but no infundibular/ suprasellar lesion, for which he underwent shunt placement without biopsy. Initial ventricular CSF showed HCG $\beta$ elevation to $129 \mathrm{ng} / \mathrm{mL}$ with no evidence of serum or CSF AFP elevations. The patient apparently achieved remission after irradiation and chemotherapy, and underwent serial imaging studies for a decade. Fourteen years after discontinuing tumor surveillance, he began experiencing episodic vertigo, double vision and an episode of syncope following a minor car accident. Subsequent scans revealed hydrocephalus and a $2 \mathrm{~cm}$ pineal region mass, and received three courses of chemotherapy (ifosphamide, etoposide and cisplatin). However, an MRI several months later demonstrated an increased tumor mass, for 
which the patient received $14.5 \mathrm{~Gy}$ stereotactic radio-surgery. Several months later, he was admitted to a tertiary care center with exam findings of bilateral ptosis, Parinaud syndrome including bilateral ophthalmoplegia, hearing loss and tinnitus. After partial resection of the recurrent tumor, his hearing improved modestly prior to initiation of further chemotherapy; he developed drug-related encephalopathy, chemotherapy was discontinued and he rapidly expired.

\section{Discussion}

Hearing impairment is an important but commonly forgotten component of Parinaud syndrome, since the pineal region is adjacent to the corpora quadrigemina; the patients discussed above, coupled with several others reported in the literature (Table 1), represent a strong history of pineal region tumors manifesting with significant hearing impairment [6].
Missori [7] observed 13 out of 72 pineal region tumors (18\%) having hearing loss/tinnitus. Islam [6] reported an 18 years old male who presented with a pineal region germinoma and hearing impairment as the chief complaint; an MRI demonstrated a well-enhanced multi-cystic tumor extending into the upper fourth ventricle and wall of the bilateral lateral ventricles [7]. Shinsato [8] reported a CT showing a high-density $35-\mathrm{mm}$ diameter tumor in the pineal region of a 49 years old woman on renal dialysis with a 4-month history of tinnitus and hearing loss [8]. Kashlan [5] observed a patient who, despite an audiogram and a brainstem auditory evoked response (BAER) test being found to be normal, had a large pineal germinoma which manifested as subacute visual and hearing impairment concomitant with symptoms of headache, nausea, vomiting and slurred speech. His subjective hearing impairment improved with his other symptoms following surgical resection. The authors stressed the importance of proceeding

Table 1: Cases of Pineal Region Tumors Manifesting as Hearing Impairment.

\begin{tabular}{|c|c|c|c|c|c|}
\hline Author (Year) & $\begin{array}{l}\text { Sex/ } \\
\text { Age }\end{array}$ & $\begin{array}{l}\text { Hearing } \\
\text { loss, later- } \\
\text { ality }\end{array}$ & Audiometric finding & $\begin{array}{l}\text { Reported cause of } \\
\text { hearing loss }\end{array}$ & $\begin{array}{c}\text { Hearing improvement } \\
\text { after treatment }\end{array}$ \\
\hline Toshniwal, et al. [9] & $\mathrm{F} / 8$ & Bilateral & SN hearing loss & $\begin{array}{l}\text { Cochlear dysfunction } \\
\text { and false localizing sign } \\
\text { of increased ICP }\end{array}$ & NK \\
\hline DeMonte, et al. [2] & M/63 & Bilateral & $\begin{array}{l}\text { Normal ability to hear } \\
\text { sounds, but had diffi- } \\
\text { culty understanding } \\
\text { speech }\end{array}$ & $\begin{array}{l}\text { Hydrocephalus and } \\
\text { a large lesion on the } \\
\text { pineal gland }\end{array}$ & $\begin{array}{l}\text { Improved clinically the } \\
\text { next day and had im- } \\
\text { proved speech discrimi- } \\
\text { nation scores }\end{array}$ \\
\hline Missori, et al. [7] & $\mathrm{F} / 47$ & Bilateral & SN hearing loss & $\begin{array}{l}\text { Pressure on brainstem } \\
\text { auditory fiber }\end{array}$ & $\begin{array}{l}\text { Audiometric examina- } \\
\text { tion was unchanged, } \\
\text { but tinnitus disap- } \\
\text { peared }\end{array}$ \\
\hline Islam, et al. [6] & $M / 18$ & Bilateral & $\begin{array}{l}\text { ABR: Prolonged } \\
\text { latencies }\end{array}$ & $\begin{array}{l}\text { Invasion and com- } \\
\text { pression of the central } \\
\text { auditory structures }\end{array}$ & Improved after VP shunt \\
\hline Haque, et al. [4] & $M / 34$ & Bilateral & $\begin{array}{l}\text { Little loss of hearing } \\
\text { level on both sides }\end{array}$ & $\begin{array}{l}\text { Compression of the } \\
\text { superior colliculus }\end{array}$ & $\begin{array}{l}\text { Improved after com- } \\
\text { plete resection of the } \\
\text { tumor }\end{array}$ \\
\hline Gaspar, et al. [3] & $M / 12$ & Bilateral & $\begin{array}{l}\text { Bilateral profound } \\
\text { perceptive hearing } \\
\text { loss }\end{array}$ & $\begin{array}{l}\text { compression of the cer- } \\
\text { ebellar peduncles, the } \\
\text { superior and inferior } \\
\text { colliculi }\end{array}$ & $\begin{array}{l}\text { Worsened after VP } \\
\text { shunt }\end{array}$ \\
\hline Shinsato, et al. [8] & $\mathrm{F} / 49$ & Unilateral & ND & $\begin{array}{l}\text { High density tumor in } \\
\text { the pineal region and } \\
\text { obstructive hydroceph- } \\
\text { alus }\end{array}$ & $\begin{array}{l}\text { Persistent after the first } \\
\text { operation }\end{array}$ \\
\hline Woo, et al. [10] & $\mathrm{F} / 45$ & Bilateral & $\begin{array}{l}\text { SN hearing impair- } \\
\text { ment }\end{array}$ & $\begin{array}{l}\text { Pineal region ganglio- } \\
\text { glioma }\end{array}$ & $\begin{array}{l}\text { Symptoms improved } \\
\text { after total excision of } \\
\text { the lesion }\end{array}$ \\
\hline
\end{tabular}




\begin{tabular}{|c|l|l|l|l|l|}
\hline Kashlan, et al. [5] & $\mathrm{M} / 32$ & Normal & $\begin{array}{l}\text { Overall decreased } \\
\text { hearing }\end{array}$ & $\begin{array}{l}\text { Moderately dense mass } \\
\text { in pineal gland region, } \\
\text { with central calcifica- } \\
\text { tion }\end{array}$ & $\begin{array}{l}\text { Normalized after mass } \\
\text { was debulked and he } \\
\text { underwent irradiation }\end{array}$ \\
\hline $\begin{array}{c}\text { Present, Case 1 } \\
\text { (2017) }\end{array}$ & $\mathrm{M} / 15$ & Bilateral & SN hearing loss & $\begin{array}{l}\text { Large posterior third } \\
\text { ventricular mass }\end{array}$ & $\begin{array}{l}\text { Tinnitus disappeared } \\
\text { and hearing normalized } \\
\text { within one week }\end{array}$ \\
\hline $\begin{array}{c}\text { Present Case 2 } \\
\text { (2017) }\end{array}$ & $\mathrm{M} / 16$ & Bilateral & $\begin{array}{l}\text { SN hearing loss- se- } \\
\text { vere on right, no } \\
\text { measurable hearing } \\
\text { on left }\end{array}$ & CN abnormalities & $\begin{array}{l}\text { Hearing remains poor: } \\
\text { deaf in left ear and 8\% } \\
\text { hearing in his right }\end{array}$ \\
$\begin{array}{c}\text { Present Case 3 } \\
\text { (2017) }\end{array}$ & M/46 & Bilateral & ND & $\begin{array}{l}\text { Hydrocephalus and } \\
\text { pineal region mass }\end{array}$ & $\begin{array}{c}\text { Hearing loss remained } \\
\text { prevalent }\end{array}$ \\
\hline
\end{tabular}

\section{ABR: Auditory brainstem response; ICP: Intracranial pressure; ND: Not done; NK= Not known; SN: Sensorineural; VP: Ventriculoperitoneal}

with intracranial imaging in patients with subjective auditory symptoms, even with normal audiologic testing, and recommended keeping pineal tumors in the differential diagnosis for patients presenting with hearing loss $[9,10]$.

Auditory symptoms are uncommonly observed due to extensive interconnections and bilateral innervations of the brainstem auditory structures. Postoperative improvement of hearing, whether subjective or assessed by audiometric studies, suggests that pressure on the acoustic fibers produces reversible damage probably related to the direct pressure exerted by pineal region tumors. These case reports and literature review should serve to sensitize physicians to these uncommon presenting symptoms of pineal region tumors.

\section{References}

1. Parinaud H (1886) Paralysis of the movement of convergence of the eyes. Brain 9(3): 330-41.

2. DeMonte F, Zelby A, Mefty O (1993) Hearing impairment resulting from a pineal region meningioma. Neurosurgery 32(4): 665-668.

3. Gaspar N, Verschuur A, Mercier G, Couanet D, Sainte-Rose C, Brugieres L (2003) Reversible hearing loss associated with a malignant pineal germ cell tumor. J Neurosur 99(3): 587-590.
4. Haque M, Ohata K, Tsuyuguchi N, Sakamoto S, Hara M (2002) A case of pineal region meningioma without dural attachment, presented with bilateral hearing impairment. Acta Neurochir 144 (2): 209-211.

5. Kashlan BN, Chick J, Kashlan ON, Ramnath S (2015) Hearing impairment in pineal tumors. J Nat Sci 1(3): e48.

6. Islam S, Asano K, Tabata H, Ohkuma H, Suzuki S (2002) Pineal region tumor manifesting initially as hearing impairment. Neurol Med Chir 42(7): 301-304.

7. Missori P, Delfini R, Cantore G (1995) Tinnitus and hearing loss in pineal region tumours. Acta Neurochir 135(3-4): 154-158.

8. Shinsato $\mathrm{Y}$, Hanada T, Kisanuki T, Yonezawa H, Yunoue $\mathrm{S}$, et al. (2012) Primary malignant melanoma in the pineal region treated without chemotherapy. Surg Neurol Int, 3(1): 123.

9. Toshniwal P, Yadava R, Goldbarg H (1986) Presentation of pinealoblastoma with ocular dipping and deafness. J Clin Neuroophthalmol 6(2): 128-136.

10. Woo PY, Teoh JY, Wong GK, Zhu XL, Siu DY, Kwan MC, et al. (2013) A 45-year-old woman with reversible bilateral hearing loss. Neurology 80(3): e23-e26.

Copyright: $\odot 2019$ Osorio DS, et al. This is an open-access article distributed under the terms of the Creative Commons Attribution License, which permits unrestricted use, distribution, and reproduction in any medium, provided the original author and source are credited. 